\author{
Ürdün'de, Lübnan'da ve Türkiye'de Mültecilerin, \\ Uygulayıcıların ve Ev Sahibi Topluluk Üyelerinin
}

Algılarını, Umutlarını ve Davranışlarını Anlamak için Antropolojik Bir Yaklaşım*

Dawn Chatty ${ }^{a}$

Öz

Modern tarihte Suriye ve Suriye halkları iki kez büyük bir yerinden edilme süreci yaşamıștır. Suriye, ilk olarak, 19. yüzyllın ortalarında ve sonunda, Osmanlı İmparatorluğu sınırlarından gelen birkaç milyonluk zorunlu göçe maruz kaldı. Daha sonra 21. yüzyılın başlarında Suriye yaşanan aşırı şiddet, büyük kitlelerin yerinden edilmelerini başlatan krizi tetiklemiştir. Dünya, ülke nüfusunun neredeyse \%10'unun boşalma hızyyla şok oldu ve Suriye sınırındaki büyüyen yerinden edilme krizine müdahale etmek isteyen insani yardım rejimi kargaşa içerisinde kaldı. Türkiye, Lübnan ve Ürdün gibi komşu devletler, iltica talep eden bu insanları etkili bir şekilde nasıl koruyacakları konusunda tereddütte kaldılar. Hiçbir ülke yerinden edilmiş bu kişiler için mülteci statüsü vermedi ve her bir ülke bu krizle başa çıkmak için geçici önlemler aldı. Pek çok durumda, ne yerinden edilmiş kişilere ne de ev sahibi topluluğa danışılmadığından ev sahibi topluluklar, yerinden edilmiş Suriyeliler ve insani yardım politikası yapıcıları ve uygulayıcıları arasında hızla gerginlikler ortaya çıkmıştır. Bu çalışmanın iki amacı vardır: birincisi, son kriz esnasında Suriyeli mültecilerin, insani yardım uygulayıcılarının ve ev sahibi toplulukların birbirinden farklı algılarını ve umutlarını ortaya çıkarmak için nitelikli, yorumlayıcı bir metodolojinin ne kadar etkili bir şekilde uygulanabileceğini ortaya koymaktır. Çalışmanın ikinci amacı ise, koşullar izin verirse, çatışma sonrası Suriyeli toplumunun yeniden bütünleşmesine olumlu anlamda katkıda bulunabilecek ev sahibi topluluklara ilişkin sosyotarihi faktörleri araştırmaktır.

Anahtar Kelimeler

Mülteciler • Ev sahipleri • Uygulayıcılar • İnsani yardım rejimi • Algı • Umut

* Bu çalışma 2014-2015 British Academy Araştırma Projesi kapsamında kısmen desteklenmiştir. Çalışmadaki görüşler yazara aittir ve British Academy'nin resmî görüşlerini yansıtmayabilir.

a $(\bowtie)$ Dawn Chatty (Dr.), Refugee Studies Centre, Department of International Development, University of Oxford, 3 Mansfield Road, Oxford OX1 3TB, United Kingdom. Eposta: dawn.chatty@qeh.ox.ac.uk

Başvuru: 18 Kasım 2016

Revizyon Gönderimi: 26 Aralık 2016

Kabul: 10 Şubat 2017

Online First: 15 Eylül 2017
Copyright ( 2017 • Uluslararası Mülteci Hakları Derneği • http://mejrs.com

ISSN 2149-4398 • elSSN 2458-8962

DOI 10.12738/mejrs.2017.2.1.0104 • Kıs 2017 • 2(1) • 35-49 


\title{
An Anthropological Approach to Understanding \\ Perceptions, Aspirations, and Behavior of Refugees, Practitioners, and Host Community Members in Jordan, Lebanon, and Turkey*
}

Dawn Chatty

\begin{abstract}
Twice in modern history, Syria and its peoples have experienced massive displacement. First, in the mid- to late 19th century, Syria received several million forced migrants from the frontiers of the Ottoman Empire; then in the early $21^{\text {st }}$ century, Syria disintegrated into extreme violence, triggering a displacement crisis of massive proportions. The speed with which the country emptied of nearly $10 \%$ of its population shocked the world and left the humanitarian aid regime in turmoil as agencies struggled to respond to the growing displacement crisis on Syria's borders. The neighboring states of Turkey, Lebanon, and Jordan were also left in a quandary regarding how to effectively protect these people who were seeking refuge. No country granted the displaced refugee status; each established temporary measures to deal with this crisis. In many cases, neither the displaced nor the host communities were consulted, and thus, tensions quickly emerged among host communities, displaced Syrians, and humanitarian policy makers and practitioners. This study has two aims: first, it sets out to explore how effectively a qualitative, interpretive methodology can be applied to elicit the different perceptions and aspirations of Syria's refugees, humanitarian assistance practitioners, and host communities during the most recent crisis, and second, it seeks to probe what sociohistorical factors related to the host communities might, when circumstances permit, positively contribute to the reintegration of Syrian society post-conflict.
\end{abstract}

Keywords

Refugees $\bullet$ Host communities $\bullet$ Practitioners $\bullet$ Humanitarian aid regime $\bullet$ Perceptions $\bullet$ Aspirations

\footnotetext{
* The preparation of this paper was supported in part by a British Academy research grant in 2014-15. The views expressed in this paper are those of the author and not necessarily those of the British Academy.

a $(\bowtie)$ Dawn Chatty (PhD), Refugee Studies Centre, Department of International Development, University of Oxford, 3 Mansfield Road, Oxford OX1 3TB, United Kingdom. Email: dawn.chatty@qeh.ox.ac.uk
}

Received: November 18, 2016 Revision received: December 26, 2016

Accepted: January 10, 2017

Online First: September 15, 2017
Copyright () 2017 - The International Refugee Rights Association • http://mejrs.com/en ISSN 2149-4398 elSSN 2458-8962

DOI 10.12738/mejrs.2017.2.1.0104 • Winter $2017 \cdot 2(1) \cdot 35-49$ 
Twice in modern history, Syria and its peoples have experienced massive displacement. First, between approximately 1860 and 1920, Syria received millions of forced migrants from the frontiers of the Ottoman Empire. The Ottoman administration, nearly overwhelmed by an excess of 2 million forced migrants from the Crimea, the Caucasus, and the Balkans at the close of the Crimean War (1853-1856) implemented a Refugee Code in 1857 to address the needs of the Tatars, Circassians, Chechnyans, Abkhaza, Abaza, and other ethnic groups who had been forcibly displaced from their homelands. By 1860, the Code had been transformed into a Commission (Muhacirin Komisyonu) that set out generous terms for resettling both the refugees and the immigrants pouring into the Empire. ${ }^{1}$ The Ottoman Migrant [Forced] and Immigrant Code, which was upgraded to a Commission in 1860 managed the resettlement of over 3 million people in the years between 1860 and the end of the Ottoman Empire in 1918. Incoming migrants were offered agricultural land, draught animals, seeds, and other support in the form of tax relief for a decade, and exemption from military service in far-flung parts of the Empire (Chatty, 2010). All effort was made to see that the settlers became self-sufficient in as short a time as possible. Their integration into local, ethnically mixed settlements was encouraged to promote and preserve the local, cosmopolitan natures of the urban and rural communities.

Then in the early $21^{\text {st }}$ century, Syria disintegrated into extreme violence triggering a displacement crisis of massive proportions. The speed with which the country emptied of nearly $10 \%$ of its population shocked the world and left the humanitarian aid regime in turmoil as it struggled to respond to the growing displacement crisis on Syria's border (United Nations High Commissioner for Refugees [UNHCR], 2016). Each country bordering on Syria has responded differently to this complex emergency: Turkey rushed to set up its own refugee camps for the most vulnerable groups but generally supported self-settlement; Lebanon refused to allow the international humanitarian aid regime to set up formal refugee camps; and Jordan prevaricated for nearly a year and then insisted on setting up a massive United Nations refugee camp. Turkey and Lebanon have permitted Syrians to enter as temporary "guests," whereas Jordan has refouled some, contrary to international norms. Lebanon and Jordan have not signed the 1951 Refugee Convention, which sets out the principles and responsibilities of states in providing protection and asylum for those deemed to fit the definition of refugee according to the 1951 Statutes and the 1967 Protocol.

1 The translation of Muhacirin into English is problematic. Some authors translate the term to mean "refugee" and others "immigrant." The Code is variously translated into English as the Refugee Code or the Immigrant Code. The Ottoman understanding of the term indicates a lack of distinction between the forced and the voluntary migrants as long as the individuals were willing to become subjects of the Ottoman sovereign. Thus, the Code - and later in 1860, the Commission - addressed both forced migrants (refugees, asylum seekers, and internally displaced peoples in contemporary $21^{\text {st }}$ century parlance) and immigrants, who were generally from Europe and seeking to start new lives in the agriculturally underpopulated regions of the Balkans and the southern provinces (see also Chatty, 2010; Kale, 2014). 
Additionally, although Turkey has signed the 1951 Convention and the 1967 Protocol, it has reserved its interpretation of the Convention to apply only to Europeans who seek refuge or asylum in Turkey. The United Nations (UN) estimates that over $60 \%$ of the Syrian refugee flow across international borders are self-settling in cities, towns, and villages where they have social networks (UNHCR, 2015-2016); in Turkey, most refugees are clustered in the southern region of the country bordering Syria, and circular migration in and out of the country is tolerated. Despite a general rejection of encampment among those who are fleeing, still some $20-25 \%$ of the Syrian refugee flow is directed into camps. In Lebanon, informal settlementsoften based on preexisting relationships with "gang-master" are proliferating, with accompanying patron-client relationships that outweigh the more participatory and transparent management of humanitarian aid. In Jordan, self-settled refugees from Syria found to be illegally working are deported into the UN refugee camps of Za'tari or Azraq, from which there is no escape other than paying to be "sponsored" by a Jordanian to leave the camp or being smuggled out and reentering the liminal state of irregular status.

Each of these states has established a variety of temporary measures to confront this crisis. Turkey has recently established a domestic regime that provides Syrians with "temporary protection," meaning, theoretically, that Syrians may not be returned to Syria. Registration with Turkish authorities is also meant to provide Syrians with health care and access to education and employment, but these measures have not been fully put into practice. In Lebanon, Syrians are treated as foreign guests; they are allowed to apply for work permits, but many cannot afford the charges, they find themselves in irregular or illegal work situations, and they are not afforded any international humanitarian protection. In Jordan, Syrians are also treated as temporary guests. They are not permitted to work and largely receive basic humanitarian assistance if they live in UNHCR-designated camps. Because fewer than $25 \%$ of Syria's refugees ${ }^{2}$ in Jordan live in camps, the majority have no legal protection.

Throughout the region, temporary, ad hoc measures are being made by policy makers and practitioners, and in most cases, the displaced Syrians and their hosting communities have not been consulted. Discrepancies are rapidly becoming visible, and tensions and protests have quickly emerged among host communities, displaced Syrians, and humanitarian policy makers. This pilot study explores the perceptions, aspirations, and behaviors of Syria's refugees, their host communities as well as policy makers in addressing the refugees' broad protection needs. It also seeks to probe what social factors within the host communities will, when circumstances permit,

2 The term "Syria's refugees" is used throughout the text to indicate that the sample population includes not only Syrian citizens but also Palestinian refugees, stateless Kurds from Syria, and other ethnic minority groups. 
positively contribute to the reshaping and reintegration of Syrian society. This study has two aims: first, to explore the methodological significance of a phenomenological anthropological and qualitative approach to data gathering and second, to examine whether a consensual view on protection in exile might be articulated in a culturally sensitive manner that does not necessarily require encampment.

\section{Research Questions}

This article is based on two fundamental research questions, one substantive and the other methodological:

1. What research methodology is most likely to elicit meaningful and reliable findings from among a deeply traumatized population?

2. What understandings exist among the three target communities regarding the basic human right to life (access to health, shelter, protection, and education of children) and survival in dignity?

\section{Methodology and Methods}

The academic study of forced migrants and refugees is fairly recent. The 1980s marked the establishment of the first two such centers: at York University in Canada and at the University of Oxford in the United Kingdom (Chatty, 2014). The latter had as its disciplinary focus law and anthropology, both the human rights of refugees and forced migrants as well as the elaboration of the lived experience through the use of anthropological and participatory approaches and tools. In the intervening period, the recognition of the enormous impact which the power differential between the researcher and the forced migrant makes has resulted in some refinement of basic anthropological tools, such as participant observation, key informant interviewing, natural group interviewing, and focus group discussions (Krulfeld \& Macdonald, 1998). Efforts to either level or minimize the power differences and the inevitable raised expectations of those interviewed have been key to eliciting replicable responses. Whereas long-term participatory observation has been the foundational element of the anthropological discipline, in forced migration studies, more rapid, short-term interaction and data collection are necessary. With this study, recognizing the shortcomings of rapid research, I set out to overcome some of these concerns by selecting local research assistants and associates who were either themselves exiles or refugees from Syria or local nationals already integrated among the refugee community through nongovernment organizations or other development work. Such an approach meant that the traditional anthropological introduction and integration into the community could be reduced to a few weeks rather than a few months. The task of building trust and confidence rested on the relationships that had already been 
established by the research assistants and associates (Bernard, 2006, pp. 210-251). Both key informant and natural group interviews were characterized by relaxed and trusting atmospheres that inspired confidence in the personal narratives, and in the elaboration of perceptions and aspirations (Skinner, 2012). The actions of the refugees and the local community members as well as practitioners were both described and observed using anthropological emic and etic approaches to data collecting by the research team.

Sample selections, locations, timing, and audiences were carefully considered in order to make the interviewees feel relaxed and unthreatened. The interview schedule - the list of key topics for the interviews was also flexible. I did not always cover all topics on the interview schedule with each interviewee because occasionally the interviewee wished to move in a different direction from the topic guide. It was important to conduct these interviews in a sensitive manner that responded to nuanced signals from the interviewees with regard to discussion topics. It was also important to divergence from the interview schedule, and to encourage individuals to reflect back on their histories of forced migration, their past and present social networks, and their plans and hopes for the future in any order they wanted. In most cases, these topics were regarded as nonthreatening, and the interviews took place among the refugee community, a natural group audience. In a few cases, the interviewee felt the need to speak only on a one-to-one basis, and I achieved this by either retreating to a bedroom or asking others to leave a communal living space. Every effort was made to recognize the sensitivity of the situation, the refugees' and forced migrants' feelings of powerlessness in the host countries as temporary guests with no international protection.

This article is based on a multi-site, 12-month, qualitative and participatory study that was conducted between October 2014 and September 2015 in Turkey, Lebanon, and Jordan,--where the majority of Syrians fleeing the civil war in their country are located; some estimates indicate that between 4 and 5 million Syrians currently reside in these three countries. Once the initial key informants were selected as described above, a snowballing technique was employed to identify additional participants for interviewing, keeping an eye on representativeness in terms of gender, class, education, ethnicity, and origins. A participant observation strategy also defined this study.

Furthermore, this study also initiated a consultative engagement between practitioners, representatives of hosting communities, and the refugees themselves. It commenced with the in-country recruitment of researchers in collaboration with the facilitating research institutions: the Swedish Institute of Istanbul in Turkey; the American University of Beirut in Lebanon; and the Council for British Research in the Levant in Jordan. The fieldwork was divided into three one-month phases in each 
country: October 2014 in Istanbul, Ankara, and Gaziantep, Turkey; December 2014 in Beirut and the Bekaa Valley, Lebanon; and February 2015 in Amman and Irbid, Jordan. Each field trip included exploratory informal and focused discussions as well as semi-structured interviewing with international and national practitioners, selfsettled refugees, and host community members as well as refugees in camps.

\section{Preliminary Observations}

In Lebanon, I had two local colleagues. The assistant in Beirut was a Lebanese national with long experience working with the Syrian community; the research associate in the Bekaa was a Syrian national in exile who was providing non-formal education to refugee children. Using some of their earlier contacts, we were able to rapidly gain access to a number of Syrians for interviews in the poorer neighborhoods of Beirut as well as the informal settlements in the Western Bekaa near Mar Elias. We also had access to Syrian refugees working with a number of international charities such as CARITAS and World Vision. The interviews with practitioners and policy makers were conducted alone [UNHCR, MSF, and Amel], largely in Beirut and in the Bar Elias/Marj districts of the Western Bekaa.

Anthropological participant observation and a careful review of the semi-structured interviews revealed significant fears, worries, and concerns among our participating interviewees. This level of confidence and openness regarding concerns, fears, and hopes was made possible through careful team ethical procedures and the use of qualitative data gathering.

What emerged from the data was a concern with the high level of social discrimination in Beirut, where Syrians were regarded as the cause [undocumented] of a rise in criminality. Many of the Syrians in Lebanon were not new to the country but had been working for many years in the construction and agriculture sectors of the economy, and the continuing armed conflict in Syria meant that many of the Syrians' wives and children had fled Syria and come to join their husbands/fathers who had already been working in Lebanon for some time. Their movements were largely progressive and in stages: first they arrived in Akkar or the Wadi Khalid region of northern Lebanon, and gradually they were able to join their spouses in the Bekaa, Tripoli, and Beirut. The men with jobs feared losing them once it was known that their families had joined them, contributing to the fear and isolation of many of these Syrians.

My husband came to Lebanon a long time ago, even before the war in Syria. He used to come over since he was 17; therefore he knows Lebanon very well. He used come and go, stay for a while [working as a carpenter], and then go back to Syria. In 2011, he was in Lebanon came and then the situation was very bad in Syria, so I came to Lebanon twice, The first time to Akkar, my husband's nephew was in Akkar, so we were waiting there for 
two weeks, but my husband didn't find work, so I went back to Syria [with the children]. Then I came back the second time, my husband had a job, and we stayed at people's houses. Back then, I couldn't go back to Hama. My husband had no intention of bringing me to Lebanon; for him it was settled that he worked in Lebanon and I stayed in Syria. But after all the explosions in Hama, I couldn't protect my kids. I decided to come and stay in Lebanon. My husband is always afraid he might be fired [if the children get into any trouble]. (Reem, Beirut, 2014)

Illegal curfews in over 40 municipalities have meant that many Syrians are afraid to go out at night, to work overtime or to mix in any way with the Lebanese population. For many of the skilled and unskilled Syrians in Lebanon, these curfews have meant that older children and adolescents are being pulled out whatever schools they attend to work during daylight hours with their fathers.

My son should now be in 9th grade, but he works in a supermarket now. But people tell me that it is a waste that my son is not in school. But our situation is very bad; I really want to send him to school, but at the same time we are in deep need of his financial help. (Layla, Beirut, 2014)

In the Bekaa Valley, Syrians with no savings are accepting very low wages in order to provide their families with food. This has raised hostility among local Lebanese who see the Syrian workers as a threat to their own livelihoods, resulting in increased social discrimination and vigilantism.

Many Syrians - despite their decades-long association with Lebanon and often their close kinship ties - feel frightened and cut off from Lebanese society. Although a number of international, national, and local NGOs operate in Beirut and in the Bekaa Valley to provide basic needs, there is little interaction with the Lebanese host community. Very little evidence emerged from the interviews of host community involvement in any survival in dignity activity on an individual basis; NGO activity was limited to more "distant and distancing" charity work or local civil society efforts in Beirut organized by middle-class Lebanese and Syrians who reside in the country. The UNHCR's very slow uptake of cash assistance to the most needy and vulnerable Syrians in Lebanon has resulted in large numbers of women and children being seen on the streets of Beirut begging, something that is generally scorned and regarded with little sympathy by the Lebanese.

I don't let my children go out on the street; I don't allow them. Only if they want to go out to buy something, but I don't let them just go out to play; I take them out myself. The people in this neighborhood are good, but other people are not so nice, and they get annoyed when they see Syrian children and get aggressive with them. I don't like to put myself or my children in critical situations where someone will curse them. It is not about Lebanon; I used to be like that in Syria as well. (Maria, Beirut 2014) 
Qualitative and participatory interviewing alongside participant observation in safe spaces that had already been established for the refugees in Lebanon revealed a high level of confidence between the interviewees and the research team, which was well-situated and integrated into the country's humanitarian aid structure. The interviewees' openness regarding their concerns over the growing vigilantism and increasing social discrimination suggested that the research team had cultivated trust and a nonhierarchical attitude.

In Jordan, one research associate, a skilled Arabic-English interpreter of Iraqi origin, and her assistant, a Syrian refugee, identified possibly key informants for interviews in Amman and its suburbs and in Irbid. These were largely refugees from the Der'aa region of southern Syria, and many had close kinship ties with Jordanians in the northern Irbid governorate. We also interviewed policy makers, practitioners, and senior government economists in Amman.

A review of participant observation notes and the forced migration life histories from the interview transcripts revealed an unusual frankness and willingness to discuss the wide range of positions of government officials, humanitarian aid agency senior officers, and local NGO workers and activists. The disparities in public opinion were also widely recognized and acknowledged in this qualitative interview process.

Jordan's initial response to the flow of Syrians from the Der'aa region into the country was open and generous. Most Syrians had kinship ties in northern Jordan or well-established social networks, and the hosting of this initial influx was positive. However, over time, the Jordanian government has restricted access to the country and actively prevented some (unaccompanied male youth) from entering or actually returned others (Palestinian refugees from Syria):

At the beginning, you had a refugee crisis with a security component, and it has become a security crisis with a refugee component. So, in the early days, it was "these are our brothers," and so the natural generosity has now given way to more suspicion about who these people are, and the security card is played all the time now. (Senior international practitioner, Amman 2015)

Most interviews with senior officials and practitioners generally acknowledged a discrepancy between what is widely written about in the local press (the burden of Syrians on the Jordanian economy) and what policy makers and practitioners felt was actually occurring; Syrians were understood to be contributing to the Jordanian economy in a greater fashion than was widely being written about in the formal press and circulated in polite society. Many senior practitioners highlighted the International Labour Organization/World Bank reports that suggested that the unemployment rate had dropped by $2 \%$ since the start of the Syrian crisis owing to the surge in newly opened Syrian-owned factories (200) and the broad employment of Jordanians (estimated at about 6,000). 
The host community in Jordan is bombarded with information regarding the negative influence of Syrian refugees in the country, although this is not backed up by the studies that are emerging. However, at the same time, there is a widespread acknowledgement that Syrians are skilled workmen, especially as carpenters, and employment in the informal sector has created stress even though it brings in much-needed funding. Syrians who are working are fearful of possible arrest because they have no work permits, even though they are largely replacing Egyptians and not Jordanians in the workforce. Those who have received cash assistance from the UN point out that their rents increase by nearly the same amount as the value of their cash transfers:

Syrian refugees are skilled craftsmen, especially carpenters-we all know that. Jordanians are not skilled carpenters. Syrians are not taking jobs from Jordanians, but they may be taking jobs from Egyptians. They are working informally, but that puts a lot of stress on them because they can be arrested and deported if they are found out. (Senior Jordanian policy maker, 2015)

The interviews clearly reflected the understanding that some social discrimination is leveled at Syrians in Jordan, but the expression is muted compared with that expressed in Lebanon. Even though the majority of Syrians in Irbid and in Amman are tied in "real" rather than fictive kinship, Jordanians keep their negative social attitudes closer to the chest. This may be associated with tribal custom and general conceptual concerns related to the requirement of hospitality toward tribal kin and others in patron/client relationships; many Syrians from the Der'aa region are associated with the Beni Khalid tribal confederation, which is also found in northern Jordan. Jordanians generally do recognize that the country benefits (from international aid) from its expenditures on refugees and that a significant percentage goes into direct government projects to assist Jordanians (e.g., a recent bilateral announcement of $\$ 1 \mathrm{~b}$ over the next three years for Jordanian infrastructure development and the construction of 50 high schools for Jordanians, before any construction may take place for Syrian students).

In Jordan, it was clear from our interviews that refugees were open in discussing their predicament. Many recognized the discrepancies between "official" rules such as no right to work and the reality on the ground that skilled Syrians such as carpenters were highly sought after by Jordanians. However, the constant pressure of working while recognizing that they could become scapegoats if caught and could be sent back across the border or into one of the two main UN refugee camps muted some of their conversations with the research team.

The methodology I employed in Jordan together with the more intimate knowledge of the senior humanitarian aid staff from earlier refugee crises meant that access to senior humanitarian aid officials and Jordanian policy makers was relatively easy to arrange. Furthermore, we were able to rapidly establish trust and confidence, which 
permitted a frankness and openness in discussions that would not have been possible with more formal methods of data collection.

In Turkey, I identified a number of research assistants-Syrian academics in exile as well as Turkish researchers - in Istanbul, Ankara, and Gaziantep to assist with interviewing refugees and members of that host community. We also interviewed humanitarian aid practitioners and policy makers in Istanbul and Gaziantep as well as representatives of human rights organizations. I visited the Nizip refugee camp in the company of a number of researchers who were associated with the Directorate General of Migration Management of the Ministry of the Interior. I also held a number of informal discussions in Arabic in the Nizip refugee camp with Syrian refugees and Turkish humanitarian aid workers. A review of these semi-formal and in-depth interviews as well as observations drawn from informal discussions revealed that there was general widespread sympathy for Syrians but not for the gypsies of the region (Nawwar). Some observers, however, had difficulty differentiating between these general Syrian populations and gypsies who may have traveled from Syria but may also have been displaced from Iraq as well as located in Turkey prior to the mass influx of Syrians across to the Hatay and southern parts of Turkey. The interviewees generally recognized the needs of Syria's refugees. They also acknowledged the importance of the third sector- the charitable organizations and religious/Sufi-based associationsin providing assistance. But street begging was widely condemned by both host community members and Syrian refugees themselves: "I don't like to give money to beggars because it just encourages them.” (Turkish practitioner, Istanbul, 2014).

Lack of communication and understanding of the situation of Syrians (fear of losing jobs; anger from others that they [Syrians] were being paid salaries) led to demonstrations, arrests, and a dozen or so deaths in October 2014; many felt that more transparency on the part of the government in terms of just what Syrians were entitled to would relieve the critical situation and growing discriminatory attitudes. Many thought that refugees from Syria were being given salaries by the Turkish government; others felt that Syrians were working for lower wages (their Turkish employers did not have to pay taxes) and that this was depriving the unskilled Turkish workers of jobs.

Support from the civil society was especially widespread among established NGOs and religious organizations related to the Islamic Sufi sector of society, that is, civil society, not religious organizations; it was common in Istanbul and in Gaziantep for neighborhood public kitchens to provide free meals and bread to the poor as well as to refugees in the area:

My husband came first, and then I joined him eight months later with our baby. At first we went to Mersin, but my husband couldn't find a job. When we ran out of money, we came to Gaziantep because the Syrian Interim Government was here; we figured there would be 
more jobs here. So we came here, and two months later, we met this nice man who found a job for my husband and rented us these two rooms. Our neighbors gave us some mattress and a TV to watch Syrian television. There is also a mosque nearby where I go, and people give me diapers for the baby, bread, and daily hot meals as well as supplies of sugar, pasta, and oil. (Hala, Gaziantep, 2014)

Lack of a common language may have been a divide in other times, but in the present crisis, language appeared to be less significant. For professionals and skilled workers, the language barrier has meant the inability to work at their professions (especially among doctors and health care specialists), but in other cases, being very different seems to have bred greater sympathy and general support.

Using a qualitative approach and permitting interviewees to move the discussion in the directions they found most comfortable allowed us gain trust and confidence organically and to collect very interesting and significant data on the perceptions of practitioners as well as refugees and the Turkish hosting communities. These interviews unveiled the complexity of ethnic relations and cross-border identities as well as the variability in the meanings of such common terms as "begging."

\section{Conclusions}

Sensitive interviewing as described earlier and an awareness of the region's modern history of displacement and dispossession meant that the interviews were conducted in an atmosphere of trust and confidence; understanding the background of forced migration in the region was particularly important in creating an atmosphere of mutual respect. Elevating the local researchers to co-interviewers and research associates also contributed to building a sense of safety and comfort in the interview contexts, and being able to ask the right questions to open up a topic with a sense of impartiality and neutrality was also important.

Using a qualitative, interpretive, and modified anthropological approach to the fieldwork and drawing the local researchers effectively into the process meant that interviewees were particularly open and trusting, often revealing details of their life experience that would rarely be brought up so early in a research relationship using standardized questionnaires and surveys. The active participation of local researchers in this qualitative and interpretive study was enormously important in creating an early atmosphere of trust and confidence.

Across the board, what emerged was that history matters and historical context matters even more. Disparity in perceptions between policy makers, practitioners, and host communities is widespread, but the disparity is not equal across the three countries, and much of the discrepancy can be linked to historical social ties and political relations between Syria and Turkey, Syria and Lebanon, and Syria and Jordan. 
In Lebanon, the consociational shape of governance and the long period of time during this crisis in which there was in effect no government led to a period of paralysis within the UN humanitarian aid system; thus, effective relief programs such as cash transfers were very late in getting started, resulting in an exponential rise in begging and other negative coping strategies (e.g., pulling young children out of school to work, moving into structures unfit for human habitation, and relying on former agricultural "gang" masters [shawish] to be the interface between the UN humanitarian relief system and the refugees themselves). All these factors together with the close ties and often extended family networks across the two countries has resulted in significant social discrimination and an unwillingness at the local level to help Syrians with basic health and education needs.

In Jordan, the majority of Syrian refugees were closely linked to the Jordanian population, especially in northern Jordan, where close tribal ties are pronounced and where original refuge was granted with host families related either by blood or marriage, particularly those fleeing from Der'aa and its surrounding villages. Jordanian sensitivity to the presence of Palestinian refugees from Syria (PRS) has resulted in draconian surveillance to identify such refugees, a dragnet that often pulls in non-Palestinian refugees from Syria. Those found to be "illegally" working are then "deported" across the border (if Palestinians from Syria) or to Azraq or Za'tari camp, creating greater mistrust and suspicion of the host government by refugees from Syria. Many Syrians consider the situation in Jordan so dire that they are preparing to return to Syria rather than face what they consider inhuman conditions any longer.

In Turkey, lessons learned have been more widely implemented in response to critical events such as demonstrations in October 2014 and widespread criticism of the lack of government transparency. The camps set up by the Turkish emergency relief organization beginning in 2012 - without the assistance of the UN experts and their camp templates - have rightly been described as five-star. These settlements are open in that the refugees may enter and leave on a daily basis, but absences of more than three weeks at a time are not tolerated because there is a long waiting list of Syrian exiles wishing to have access to these camps.

Although the interviewing in Turkey took place before the announcement of the domestic law that provided Syrians with formal IDs and temporary protection (as well as rights to health and education and permission to apply for work permits) in January 2015, it was clear that Turkey — of all three countries — was far more humane and practical in its approach to the mass influx of refugees from Syria, even despite a language barrier that does not exist in Lebanon or Jordan. Social discrimination was at its least public expression, and Sufi-based organizations were active in providing assistance at the local community level, mainly hot meals and community-supported 
accommodation. Many members of such organizations expressed their concerns to provide refuge for the Syrians in their country in terms of obligations both religious and ethical, and much of their activity has permitted a form of local accommodation in Turkey that is not found in Lebanon or Jordan despite the closer linguistic and social ties in the latter two countries. Social cohesion is strong, which bodes well for eventual local integration in Turkey or return to Syria as a friendly and supportive neighboring state whatever political solution may finally emerge.

The disparity in perceptions among refugees, members of local hosting communities, and practitioners is especially pronounced in Lebanon and Jordan, where the international humanitarian aid regime is the most active. The engagement of UN frameworks in creating an architecture of assistance is built upon templates developed over the past few decades largely among poor, agrarian, developing countries, but such policies and practices do not fit easily into the middle-income countries of the Eastern Mediterranean among a refugee population that is largely educated and also middle-class. Without a serious effort to make the humanitarian solutions fit the context of the Middle East, success will continue to be muted at best and damaging at worst.

It is ironic that Turkey, the one country that has not requested assistance from the UN refugee agency, seems to have managed the process of providing assistance without undermining refugee agency and dignity. Largely working alone with local staff drawn from the Turkish civil service as well as the Disaster Management Unit of the Prime Minister's Office (AFAD) and the main quasi-official Turkish NGO (IHH), Turkey has managed the Syrian refugee crisis with sensitivity and concern. The separate histories of Turkey and the countries of the Levant have obviously contributed to the disparities in perceptions, aspirations, and behavior among refugees, host community members, and practitioners in each of the three countries. The moderated engagement of the international humanitarian aid community in Turkey but not in Lebanon and Jordan has also contributed to some of the disparities noted in this study. Global templates for humanitarian assistance built from experiences in very different contexts and among populations of significantly different makeup are not easily integrated into Middle Eastern concepts of refuge, hospitality, and charity. The close social ties and networks of Syrians in Lebanon and Jordan but not in Turkey (with the exception of the Hatay) have meant that the initial generosity of hosting among relatives in a wide social network has more rapidly given way to hostility and discrimination, unlike the situation in Turkey, where fewer Syrians had social networks and the original hosting was based on a religious and ethical sense of duty to the stranger. 


\section{References}

Bernard, R. (2006). Research methods in anthropology: Qualitative and quantitative approaches (4th ed.). Lanham, New York, Toronto and Oxford: Altamira Press.

Chatty, D. (2010). Displacement and dispossession in the modern Middle East. Cambridge, UK: Cambridge University Press.

Chatty, D. (2014). Anthropology and forced migration. In E. Fiddian-Qasmiyeh, G. Loescher, K. Long, \& N. Sigona (Eds.), The Oxford handbook of refugee and forced migration studies (pp. 74-85). Oxford, UK: Oxford University Press.

Krulfeld, R., \& Macdonald, J. (Eds.). (1998). Power, ethics and human rights: Anthropological studies of refugee research and action. Boston and Oxford: Rowman and Littlefield.

Skinner, J. (2012). The interview: An ethnographic approach. ASA monograph 49. New York and Oxford: Berg Press.

United Nations High Commissioner for Refugees. (2015-2016). Regional refugee and resilience plan. Retrieved April 6, 2016 from www.3rpsyriacrisis.org/wp-content/uploads/.../3RP-ReportOverview.pdf

United Nations High Commissioner for Refugees. (2016). Syria regional response plan (2014). Retrieved April 6, 2016 from http://www.unhcr.org/syriarrp6/ 